\title{
CONHECIMENTO DOS DOCENTES E DISCENTES DE ENFERMAGEM SOBRE O
} SUPORTE BÁSICO DE VIDA

\section{KNOWLEDGE OF PROFESSORS AND STUDENTS ON BASIC LIFE SUPPORT \\ CONOCIMIENTOS PROFESORES Y ESTUDIANTES SOBRE APOYO BÁSICO A LA VIDA}

\begin{abstract}
Anderson Brito de Medeiros ${ }^{1}$, Izaura Luzia Silvério Freire ${ }^{2}$, Fernanda Rafaela dos Santos ${ }^{3}$, Bárbara Coeli Oliveira da Silva ${ }^{4}$, George Felipe de Moura Batista ${ }^{5}$, Márcio Moreira de
\end{abstract} Menezes $^{6}$

Como citar esse artigo: Medeiros AB, Freire ILS, Santos FR, Silva BCO, Batista GFM, Menezes MM. Conhecimento dos docentes e discentes de enfermagem sobre o suporte básico de vida. Rev Enferm Atenção Saúde [Internet]. 2021 [citado em:___]; 10(1): e202102. doi: https://doi.org/ 10.18554/reas.v10i1.4163

\section{RESUMO}

Objetivo: identificar o conhecimento dos docentes e discentes de enfermagem de uma universidade pública sobre suporte básico de vida. Método: estudo exploratório-descritivo, com delineamento transversal e abordagem quantitativa realizado por meio de questionário com docentes e discentes do curso técnico em enfermagem e docentes da graduação em enfermagem. Resultados: observou-se maior conhecimento dos participantes referente ao ambiente onde se pode realizar a ressuscitação cardiopulmonar $(88,4 \%)$, aos sinais clínicos que identificam uma parada cardiorrespiratória $(77,5 \%)$, à relação compressão-ventilação $(71,3 \%)$, aos elos da cadeia de sobrevivência $(56,6 \%)$ e à profundidade das compressões torácicas $(55,0 \%)$. Em outras questões, porém, ocorreu percentual expressivo de erros, tais como situações especiais para utilização do desfibrilador externo automático $(93,8 \%)$, sinais da parada respiratória $(69,8 \%)$, ritmos chocáveis $(65,1 \%)$ e frequência das compressões torácicas $(50,4 \%)$. Conclusão: o estudo demonstrou conhecimento importante sobre suporte básico de vida entre os pesquisados. Contudo, houve erros em situações pontuais relativas ao questionário.

Descritores: Reanimação Cardiopulmonar; Parada Cardíaca; Docentes de Enfermagem; Estudantes de Enfermagem; Educação em Enfermagem.

\footnotetext{
${ }^{1}$ Enfermeiro. Doutorando em Enfermagem da Universidade Federal do Rio Grande do Norte. Enfermeiro da Secretaria Municipal de Saúde de Natal. Natal-RN. http://orcid.org/0000-0003-2315-2034

${ }^{2}$ Enfermeira. Doutora em Enfermagem. Professora da Escola de Saúde da Universidade Federal do Rio Grande do Norte. Natal-RN. http://orcid.org/0000-0002-2687-5759

3 Enfermeira. Mestranda em Enfermagem da Universidade Federal do Rio Grande do Norte. Natal-RN. http://orcid.org/0000-0002-6538-9411

${ }^{4}$ Enfermeira. Doutoranda em Enfermagem da Universidade Federal do Rio Grande do Norte. Enfermeira da Secretaria de Estado da Saúde Pública do Rio Grande do Norte e Secretaria Municipal de Saúde de Parnamirim. Natal-RN. http://orcid.org/0000-0002-2933-0930

${ }^{5}$ Discente do Curso de Graduação em Medicina da Universidade Federal do Rio Grande do Norte. Natal-RN. http://orcid.org/0000-0003-4981-5270

${ }^{6}$ Médico. Residente em Ginecologia e Obstetrícia da Universidade Federal do Rio Grande do Norte. Natal-RN. http://orcid.org/0000-0002-7837-9503
} 


\begin{abstract}
Objective: to identify the knowledge of nursing professors and students from a public university on basic life support. Method: exploratory-descriptive study, with cross-sectional design and quantitative approach, conducted by means of a questionnaire with professors and students from the technical nursing course and professors from the undergraduate nursing course. Results: there was a greater knowledge of the participants regarding the environment where cardiopulmonary resuscitation may be performed $(88.4 \%)$, the clinical signs that identify a cardiorespiratory arrest $(77.5 \%)$, the compression-ventilation ratio $(71.3 \%)$, the links in the survival chain $(56.6 \%)$ and the depth of thoracic compressions $(55.0 \%)$. On other questions, however, there was a significant percentage of errors, such as: special situations for using the automatic external defibrillator (93.8\%), signs of respiratory arrest $(69.8 \%)$, shockable rhythms $(65.1 \%)$ and frequency of thoracic compressions (50.4\%). Conclusion: the study demonstrated important knowledge on basic life support among those surveyed. Nevertheless, there were errors in specific situations related to the questionnaire.

Descriptors: Cardiopulmonary Resuscitation; Cardiac Arrest; Nursing Professors; Nursing Students; Nursing Education.
\end{abstract}

\title{
RESUMEN
}

Objetivo: identificar los conocimientos de profesores y estudiantes de enfermería de una universidad pública sobre soporte vital básico. Método: estudio exploratorio-descriptivo, con diseño transversal y enfoque cuantitativo, realizado a través de un cuestionario con profesores y estudiantes del curso técnico en enfermería y profesores de pregrado en enfermería. Resultados: hubo un mayor conocimiento de los participantes sobre el entorno donde se puede realizar la reanimación cardiopulmonar $(88,4 \%)$, los signos clínicos que identifican una parada cardiorrespiratoria $(77,5 \%)$, la relación compresión-ventilación $(71,3 \%)$, los eslabones de la cadena de supervivencia $(56,6 \%)$ y la profundidad de las compresiones torácicas $(55,0 \%)$. En otras cuestiones, sin embargo, hubo un porcentaje significativo de errores, tales como: situaciones especiales de uso del desfibrilador externo automático $(93,8 \%)$, signos de parada respiratoria $(69,8 \%)$, ritmos desfibrilables $(65,1 \%)$ y frecuencia de las compresiones torácicas $(50,4 \%)$. Conclusión: el estudio demostró importantes conocimientos sobre soporte vital básico entre los encuestados. Sin embargo, hubo errores en situaciones específicas relacionadas con el cuestionario.

Descriptores: Reanimación Cardiopulmonar; Parada Cardiaca; Profesores de Enfermería; Estudiantes de Enfermería; Educación en Enfermería.

\section{INTRODUÇÃO}

A partir de 1960, pesquisas relacionadas à parada cardiorrespiratória (PCR) obtêm destaques na comunidade científica com reflexão direta na cientificidade e padronização da assistência prestada ao indivíduo acometido por esse evento. Técnicas e manobras começaram a ser desenvolvidas a partir de estudos sistemáticos e revisões de literatura a fim de promover a recuperação das funções cardíacas, respiratórias e encefálicas, fenômeno que fundamenta a Ressuscitação Cardiopulmonar (RCP). ${ }^{1}$

A RCP consiste no tratamento da PCR, desenvolvendo-se por meio de uma abordagem de fases e algoritmos, com objetivo de manter a perfusão de órgãos 
nobres, restaurá-la o mais breve possível e minimizar a lesão encefálica. Com base na possibilidade de vigência da situação supracitada, as equipes de saúde devem estar preparadas para eventos de urgência e emergência, nos quais o enfermeiro deve apresentar aptidão para dar início ao suporte básico de vida (SBV) e auxílio ao suporte avançado de vida (SAV). Para que isso ocorra de modo seguro, é importante que receba, durante a sua formação, o conhecimento e as habilidades necessárias para o desempenho adequado nessas situações. $^{2}$

Ressalta-se que o SBV consiste na articulação de métodos sistematizados e objetivos em busca da resolução da urgência com ênfase no acionamento do serviço de emergência, compressões torácicas e suporte ventilatório. Acerca disso, o suporte avançado de vida (SAV) traz o ambiente hospitalar enquanto cenário. Nesse processo, estudos randomizados mostram que a vigilância e prevenção são fatores essenciais para a minimização do número de óbitos. ${ }^{3}$

Portanto, o conhecimento e habilidade dos profissionais de enfermagem devem estar entrelaçados de forma a subsidiar e garantir assistência eficiente e qualificada, visto que o atendimento ao paciente vítima de PCR deve ser prestado com rapidez e segurança. Para tal, é indispensável o domínio de todos os processos relacionados à cadeia de sobrevivência por esses trabalhadores, seja no ambiente intra ou extra-hospitalar, aspectos esses que devem ser, inclusive, de conhecimento da população leiga. ${ }^{4}$

Cabe, portanto, às instituições de ensino o oferecimento de treinamento adequado aos docentes sobre o SBV a fim de capacitá-los para que além de estarem aptos para agir em situações de emergência, saibam preparar seus alunos quanto aos procedimentos técnicos e atualizados dessas situações. A partir dessas considerações, objetiva-se identificar o conhecimento dos docentes e discentes de enfermagem de uma universidade pública federal sobre o suporte básico de vida.

\section{MÉTODO}

Estudo exploratório-descritivo, com delineamento transversal e abordagem quantitativa, realizado com docentes da graduação e curso técnico em Enfermagem e discentes do curso técnico em Enfermagem de uma universidade pública federal do Nordeste do Brasil. A coleta dos dados ocorreu no período de fevereiro a abril de 2017 por meio de um questionário estruturado com questões fechadas. A amostra se constituiu por 40 docentes e 89 discentes da referida universidade com base no seguinte critério de inclusão: ser docente 
ou discente em exercício ativo na instituição. Como exclusão, adotou-se o preenchimento de menos de $90 \%$ da parte II do questionário, mas não houve perda amostral.

O instrumento de coleta de dados utilizado foi um questionário elaborado pelos pesquisadores, baseado nos fundamentos preconizados pela literatura científica sobre o assunto. A ferramenta foi validada em duas etapas: a primeira por juízes selecionadas a partir da plataforma lattes; e a segunda por profissionais do Núcleo de Educação Permanente (NEP) do Serviço de Atendimento Móvel de Urgência (SAMU) 192/Natal e SAMU 192/RN. Houve pequenas modificações na redação, estruturação, conteúdo, sequência, categorização e codificação das informações do questionário com o objetivo de melhorar sua aplicabilidade e adequação aos propósitos do estudo.

A versão final do instrumento foi composta por duas partes. A parte I se refere aos dados relacionados à caracterização sociodemográfica dos docentes e discentes, tais como idade, sexo, estado civil, titulação máxima (para o docente) e período do curso (para o discente). A parte II aborda o conhecimento dos participantes sobre o Suporte Básico de Vida (SBV) em cardiologia. Para tal, contém nove perguntas de múltipla escolha com cinco opções de respostas, além de uma questão com cinco opções de respostas em V (verdadeiro) ou F (falso).

Questão 1: O primeiro elo da cadeia de sobrevivência de Parada Cardiorrespiratória Extra-Hospitalar (PCREH) é: a) A Ressuscitação Cardiopulmonar (RCP) imediata e de alta qualidade; b) $\mathrm{O}$ reconhecimento e acionamento do serviço médico de emergência; c) O Serviço médico básico e avançado de emergência; d) A rápida desfibrilação; e) Não sei informar.

Questão 2: A ressuscitação cardiopulmonar (RCP) é um procedimento: a) Exclusivamente do ambiente intrahospitalar; b) Exclusivamente do ambiente extra-hospitalar; c) Que ocorre no ambiente intra e extra-hospitalar; d) Ocorre exclusivamente no ambiente intrahospitalar nas unidades de emergência e terapia intensiva; e) Não sei informar.

Questão 3: São sinais clínicos de uma parada cardiorrespiratória (PCR): a) Ausência de responsividade, respiração presente e com pulso central palpável; b) Ausência de responsividade, respiração ausente ou agônica e sem pulso central palpável; c) Presença de responsividade, respiração presente e sem pulso central palpável; d) Presença de responsividade, 
respiração ausente ou agônica e com pulso central palpável; e) Não sei informar.

Questão 4: Deve-se suspeitar de parada respiratória quando o paciente se apresentar: a) Responsivo ao estímulo, com respiração agônica ou ausente, sem pulso periférico palpável; b) Responsivo ao estímulo, com respiração agônica ou ausente, com pulso periférico palpável; c) Irresponsivo ao estímulo, com respiração agônica ou ausente, sem pulso central palpável; d) Irresponsivo ao estímulo, com respiração agônica ou ausente, com pulso central palpável; e) Não sei informar.

Questão 5: É sensato que os profissionais de saúde durante o suporte básico de vida (SBV) apliquem compressões torácicas e ventilações em todos os pacientes adultos com parada cardiorrespiratória (PCR) em uma relação de: a) 3 compressões e 1 ventilação; b) 5 compressões e 1 ventilação; c) 15 compressões e 2 ventilações; d) 30 compressões e 2 ventilações; e) Não sei informar.

Questão 6: Os Desfibriladores Externos Automáticos (DEA) são equipamentos computadorizados de operação simples e capazes de identificar os ritmos chocáveis e administrar choques. Nesse contexto, são considerados ritmos chocáveis na parada cardiorrespiratória: a) Fibrilação ventricular e taquicardia ventricular sem pulso; b) Atividade elétrica sem pulso e assistolia; c) Taquicardia ventricular sem pulso e atividade elétrica sem pulso; d) Assistolia e fibrilação ventricular; e) Não sei informar.

Questão 7: Sobre as situações especiais para a utilização do Desfibrilador Externo Automático (DEA), é correto afirmar: a) Se a vítima apresentar excesso de pelos no tórax, deve-se remover o pelo de todo o tórax da vítima; b) Se o paciente estiver com o tórax molhado, deve-se secar o local onde serão posicionadas as pás; c) Se a vítima apresentar adesivos de medicamentos/hormonais, deve-se remover somente se estiverem no local onde serão posicionadas as pás; d) Se a vítima estiver em uma poça d'água, não há problemas, mesmo que a poça d'água também envolva o socorrista que for aplicar o choque; e) Não sei informar.

Questão 8: Em adultos a profundidade de compressões torácicas é de: a) Cerca de 2,5 centímetros; b) Pelo menos 5 e não superior a 6 centímetros; c) Mais de 6 centímetros; d) Entre 6 a 7 centímetros; e) Não sei informar. 
Questão 9: A frequência recomendada para as compressões torácicas em procedimento de Ressuscitação Cardiopulmonar é: a) No mínimo 90 e no máximo 100/ compressões por minutos; b) No mínimo 90 e no máximo 110/ compressões por minutos; e) No mínimo 100 e no máximo 120/ compressões por minutos; d) No mínimo 100 e no máximo 140/ compressões por minutos; e) Não sei informar.

Questão 10: Para obter uma Ressuscitação Cardiopulmonar de alta qualidade para adultos, coloque $\mathrm{V}$ para Verdadeiro e F para Falso: a) ( ) É indicado, no portador de marca-passo (MP), que as pás sejam aplicadas a $8 \mathrm{~cm}$ de distância do MP ou que o socorrista opte por outro posicionamento das pás; b) ( ) É recomendado que o socorrista se apoie sobre o tórax da vítima durante as compressões para não ocorrer fadiga do socorrista; c) ( ) É indicado que se interrompa as compressões por pelo menos de 15 segundos para avaliação do pulso; d) ( ) É recomendado que se administre cada ventilação em 1 segundo, promovendo a elevação do tórax; e) ( ) Não sei informar.

Todos os princípios éticos e legais que regem a pesquisa em seres humanos foram obedecidos, preconizados na
Resolução do Conselho Nacional de Saúde No 466/12, manifestado pela aprovação do protocolo do registro do Comitê de Ética e Pesquisa da Universidade Federal do Rio Grande do Norte (CEP-UFRN) $\mathrm{n}^{\circ}$ 1.489.098/2016 e Certificado de apresentação para Apreciação Ética (CAAE) no 54295016.1.0000.5537.

Os dados foram organizados em uma planilha eletrônica e apresentados em tabelas com frequência relativa e absoluta. Para tanto, utilizou-se a estatística descritiva e o software Microsoft Excel.

\section{RESULTADOS}

Ao caracterizar o perfil sociodemográfico dos pesquisados, observou-se que a maior parte dos discentes possuía menos de 20 anos, com idade mínima de 16 e máxima de 44 anos, além de média de idade de 25,6 anos. A maioria era do sexo feminino $(86,5 \%)$, solteira $(69,7 \%)$ e cursava do primeiro ao quinto período do curso técnico em Enfermagem, com predominância dos alunos do terceiro período (36,0\%). Com relação aos docentes, a maior parte estava na faixa etária de 41 a 50 anos $(38,1 \%)$, com idade mínima de 30 anos, máxima de 62 anos e média das idades de 41,1 anos. Além disso, eram casados $(57,5 \%)$ e tinham como titulação máxima o doutorado $(65,0 \%)$. 
Quanto às perguntas do questionário (Tabela 1), observou-se na primeira questão um, relativa ao primeiro elo da cadeia de sobrevivência no ambiente extra-hospitalar, que a maioria dos respondentes assinalou a alternativa correta $(56,6 \%)$. A segunda questão, por sua vez, inquiriu ao participante sobre a localização da RCP; e $88,4 \%$ dos participantes responderam corretamente. Ressalta-se, aliás, que todos os docentes acertaram a referida pergunta.

Em situações restritas, como aquelas relativas a situações especiais em Suporte Básico de Vida, parcela significativa dos entrevistados respondeu de modo incorreto. Foi o caso das questões de número quatro, referente ao desenvolvimento de suspeita de PCR (69,8\% de erros); seis, sobre ritmos chocáveis na parada cardiorrespiratória

Tabela 1 - Conhecimento dos docentes e discentes de enfermagem sobre o suporte básico de vida em cardiologia no adulto. Natal-RN, Brasil, 2017

\begin{tabular}{llllllll}
\hline Questões & Respostas & \multicolumn{2}{l}{ Docentes } & \multicolumn{2}{l}{ Discentes } & \multicolumn{2}{c}{ Total } \\
& & $\mathbf{n}$ & $\mathbf{\%}$ & $\mathbf{n}$ & $\mathbf{\%}$ & $\mathbf{n}$ & $\%$ \\
\hline Qestão 1 & Certo & 29 & 22,5 & 44 & 34,1 & 73 & 56,6 \\
& Errado / não sabe & 11 & 8,5 & 45 & 34,9 & 56 & 43,4 \\
Questão 2 & Certo & 40 & 31,0 & 74 & 57,4 & 114 & 88,4 \\
& Errado / não sabe & 0 & 0,0 & 15 & 11,6 & 15 & 11,6 \\
Questão 3 & Certo & 37 & 28,7 & 63 & 48,8 & 100 & 77,5 \\
& Errado / não sabe & 3 & 2,3 & 26 & 20,2 & 29 & 22,5 \\
Questão 4 & Certo & 19 & 14,7 & 20 & 15,5 & 39 & 30,2 \\
& Errado / não sabe & 21 & 16,3 & 69 & 53,5 & 90 & 69,8
\end{tabular}




\begin{tabular}{llllllll} 
Questão 5 & Certo & 29 & 22,5 & 63 & 48,8 & 92 & 71,3 \\
& Errado / não sabe & 11 & 8,5 & 26 & 20,2 & 37 & 28,7 \\
Questão 6 & Certo & 22 & 17,1 & 23 & 17,8 & 45 & 34,9 \\
& Errado / não sabe & 18 & 14,0 & 66 & 51,2 & 84 & 65,1 \\
Questão 7 & Certo & 4 & 3,1 & 4 & 3,1 & 8 & 6,2 \\
& Errado / não sabe & 36 & 27,9 & 85 & 65,9 & 121 & 93,8 \\
Questão 8 & Certo & 25 & 19,4 & 46 & 35,7 & 71 & 55,0 \\
& Errado / não sabe & 15 & 11,6 & 43 & 33,3 & 58 & 45,0 \\
Questão 9 & Certo & 24 & 18,6 & 40 & 31,0 & 64 & 49,6 \\
& Errado / não sabe & 16 & 12,4 & 49 & 38,0 & 65 & 50,4 \\
\hline
\end{tabular}

A Figura 1, por fim, apresenta as respostas referentes à questão 10 , que se baseia em especificidades do Suporte Básico de Vida. Nas opções de respostas, os pesquisados teriam que colocar $\mathrm{V}$ (verdadeiro) ou $\mathrm{F}$

Figura 1 - Conhecimento dos docentes e discentes de enfermagem sobre a ressuscitação cardiopulmonar de alta qualidade para adultos. Natal-RN, Brasil, 2017 


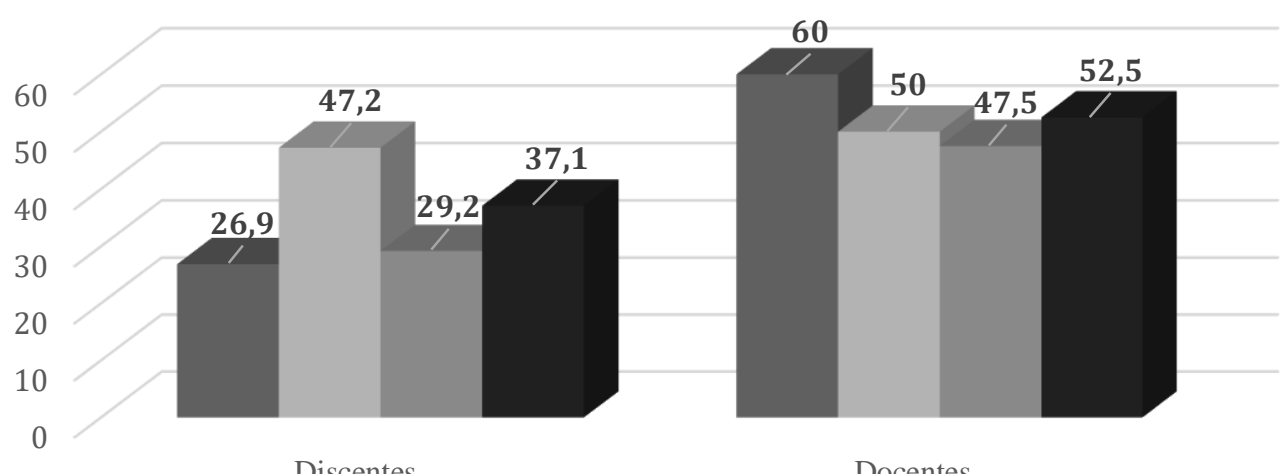

Discentes Docentes

שÉ indicado no portador de marca-passo (MP) que as pás sejam aplicadas a $8 \mathrm{~cm}$ de distância do MP ou que o socorrista opte por outro posicionamento das pás.

É recomendado que o socorrista se apoie sobre o tórax da vítima durante as compressões para não ocorrer fadiga do socorrista.

ఐÉ indicado que se interrompa as compressões por pelo menos 15 segundos para avaliação de pulso.

匹É indicado que se administre cada ventilação em 1 segundo, promovendo a elevação do tórax.

\section{DISCUSSÃO}

As características dos docentes e discentes de enfermagem referentes ao sexo seguem outras pesquisas realizadas na área, que mostram a predominância de mulheres. ${ }^{2,5}$ Com relação à titulação dos docentes, percebeu-se expressivo percentual de doutores, o que nos mostra que a pós-graduação stricto sensu em Enfermagem no Brasil tem crescido nos últimos anos e contribuído para melhorar a qualificação dos enfermeiros assistenciais e docentes de Enfermagem. ${ }^{6}$

Quanto aos resultados da parte II do questionário, verificou-se que, na questão referente aos elos da cadeia de sobrevivência no ambiente extra-hospitalar, $56,6 \%$ dos participantes optaram pela alternativa correta. $\mathrm{Na}$ verdade, estudos semelhantes realizados com estudantes de Enfermagem em universidades brasileiras mostram importante diferença estatística entre os conhecimentos sobre essa questão, com variação de acertos de 29,3\% a $84,4 \%$. $^{5,7}$

Ressalta-se que os elos da cadeia de sobrevivência são elementos essenciais a serem seguidos no atendimento de uma PCR. Quanto ao tema, as atualizações mais recentes das diretrizes de RCP enfatizam a necessidade de cadeias de sobrevivência distintas com a finalidade de identificar as diferentes vias de cuidados dos pacientes que sofrem PCR no hospital ou no ambiente extra-hospitalar. $^{8}$

Nesse contexto, a assistência ao paciente que apresenta uma PCR intrahospitalar (PCRIH) deve ter início com a 
vigilância e prevenção, sucedidas pelo reconhecimento e acionamento do serviço médico de emergência; início de RCP imediata, de alta qualidade e com rápida desfibrilação; e instalação de suporte avançado de vida mais cuidados pós-PCR. $\mathrm{Na}$ PCR extra-hospitalar (PCREH), por outro ângulo, deve-se iniciar a assistência pelo reconhecimento e acionamento do serviço médico de emergência com priorização à RCP imediata e de alta qualidade; busca por uma rápida desfibrilação; e finalização com o suporte avançado de vida e cuidados pós-PCR. ${ }^{8}$

No tocante ao ambiente onde se realiza a RCP, todos os docentes responderam corretamente, ao afirmarem que pode ocorrer no ambiente intra e extrahospitalar. No entanto, alguns alunos $(11,6 \%)$ ainda apresentavam uma compreensão errônea acerca do tema. Apesar das últimas atualizações das diretrizes de RCP reforçarem especificidades distintas no atendimento à PCR ocorrida no hospital e ambiente extrahospitalar, a emergência referente ao atendimento à pessoa acometida pelo evento independe do cenário onde ocorra, devendo-se sempre buscar a estabilização da vítima e recuperação de seu estado de saúde. ${ }^{8,9}$

Nesse ínterim, reforça-se a necessidade de que a própria população leiga tenha ciência dos sinais clínicos que identificam uma PCR, dentre os quais se destacam a perda de consciência, ausência de pulso central, respiração ou gasping. Afinal, todo cidadão deve apresentar participação ativa na prestação de assistência ao indivíduo em risco de vida iminente, exceto em situações nas quais a própria segurança esteja em perigo. A despeito disso, são escassas as capacitações relacionadas a esses indivíduos na vida diária, o que se reflete em maiores dificuldades para apreensão e utilização dos conhecimentos sobre SBV. ${ }^{10}$

Entre profissionais da saúde, não somente a teoria referente ao tema é necessária, mas também sua capacidade de aplicação prática de modo rápido e eficaz, o que também nem sempre é verificado. No presente estudo, por exemplo, 22,5\% do total de entrevistados desconheciam os sinais e sintomas apresentados pelos pacientes em parada cardiorrespiratória, fato que também foi percebido em outra pesquisa realizada com graduandos de Enfermagem no Brasil. ${ }^{5}$

Sobre a relação compressãoventilação no paciente adulto em PCR, a maioria dos pesquisados identificou a alternativa correta (71,3\%). Quanto ao tema, as novas diretrizes de RCP destacam que quando o atendimento é realizado por um único socorrista, deve-se iniciar com 30 
compressões para 2 ventilações, em frequência de 100 a 120 vezes por minuto. Se o socorrista for leigo, porém, deve priorizar somente as compressões até a chegada da ajuda, dado que, nessas circunstâncias, os benefícios neurológicos são semelhantes. ${ }^{8}$

Acredita-se que o sucesso da RCP está intrinsecamente relacionado a uma desfibrilação precoce, que é ideal dentro dos primeiros três a cinco minutos após a PCR. Na verdade, cada minuto decorrido do início do evento arrítmico súbito sem desfibrilação diminui as chances de sobrevivência em 7 a 10\%. Com base nisso, é indispensável que a enfermagem tenha conhecimento sobre os tipos de ritmos de uma PCR e reconheça a importância de aplicar a desfibrilação o mais rápido possível. ${ }^{11-13}$

Contrapondo o exposto acima, ao serem questionados sobre os ritmos que respondem ao choque como tratamento, a maioria dos participantes $(65,1 \%)$ do estudo optou por alternativas incorretas. Salientase que a PCR pode se apresentar em quatro ritmos: taquicardia ventricular sem pulso (TVSP), fibrilação ventricular (FV), atividade elétrica sem pulso (AESP) e assistolia, dos quais apenas dois são considerados chocáveis (TVSP e FV). Caso isso não seja de conhecimento da equipe, as consequências relacionadas ao choque ou a sua ausência podem ser catastróficas e, inclusive, implicar no óbito do paciente. ${ }^{12,14}$

Acerca do DEA, é um equipamento portátil capaz de interpretar o ritmo cardíaco, além de selecionar o nível de energia e dar ao operador a função de pressionar somente o botão de choque, quando indicado. Na prática clínica, é o grande responsável pela recuperação de pacientes em PCR, fato que, no meio jurídico, reflete no desenvolvimento de projetos de lei como o de número 735 de 2015, dedicado à obrigatoriedade quanto à disponibilização do DEA em locais de todo o território nacional com grande circulação de pessoas. ${ }^{11,15}$

É claro que a legislação supracitada é apenas o primeiro passo para tornar viável o uso do aparelho enquanto medida salvadora em situações de emergência. Outras necessidades incluem determinação de locais públicos com alta incidência de eventos cardiovasculares; investigação das razões pelas quais não se utiliza o DEA em determinados momentos em que o aparelho está disponível; e mensuração da melhora na sobrevida dos pacientes submetidos ao uso do DEA por socorristas leigos. ${ }^{16}$

No que concerne às situações especiais para a utilização da ferramenta, poucos participantes $(6,2 \%)$ responderam corretamente, dados esses que se contrapõem à pesquisa realizada com 
acadêmicos de Enfermagem de uma universidade pública brasileira. Nessa última instituição, mais de $50 \%$ dos entrevistados compreendiam a conduta correta a ser tomada em situações específicas, como uso do desfibrilador em pacientes em contato com água. ${ }^{5}$

Outras ocasiões consideradas singulares para o uso do equipamento é a presença de portadores de marca-passo (MP) ou cardioversor-desfibrilador implantável localizado na região indicada para a aplicação das pás. Nesse último caso, deve-se afastá-las pelo menos $8 \mathrm{~cm}$ ou posicioná-las em outro local, já que se estiverem muito próximas do MP ou cardioversor-desfibrilador implantável podem prejudicar a análise do ritmo pelo desfibrilador externo. ${ }^{11}$

Quanto à profundidade das compressões torácicas, as novas diretrizes de RCP recomendam que sejam de no mínimo 5 e no máximo 6 centímetros, com permissão do retorno do tórax ao final de cada compressão. ${ }^{10}$ Sobre esse item, a maior parte dos participantes $(55,0 \%)$ respondeu corretamente. No entanto, quando questionados sobre a frequência de compressões torácicas recomendadas na $\mathrm{RCP}$, a maioria respondeu de forma incorreta $(50,4 \%)$, fato que se mostra ainda pior em outro trabalho realizado com estudantes de Enfermagem brasileiros. ${ }^{5}$
As atualizações das diretrizes de RCP formuladas pela American Heart Association em 2020 afirmam que, em vítimas adultas de PCR, os socorristas devem aplicar compressões torácicas a uma frequência de 100 a 120/min. ${ }^{8}$ Quanto ao assunto, estudo realizado em uma instituição de ensino superior do Sudeste do Brasil verificou o conhecimento dos discentes de Enfermagem sobre RCP em SBV, obtendo percentual de acertos inferior ao do presente estudo em relação à frequência e profundidade das compressões torácicas $(38,7 \%$ e $6,7 \%$, respectivamente). Contudo, após receberem capacitação adequada, cerca de $89,0 \%$ dos entrevistados responderam a essas questões de modo adequado, o que reforça a necessidade de capacitações frequentes relacionadas ao SBV ainda durante a graduação. ${ }^{5}$

$\mathrm{Na}$ verdade, até mesmo o ensino sobre SBV ainda no ambiente escolar, destinado a crianças e adolescentes, pode ser efetivo, a depender do modo como é empregado. Além de recomendada pela Organização Mundial da Saúde, a instrução do tema demonstrou ser capaz de solidificar os conhecimentos relativos à RCP na vida adulta, ainda que boa parte dos investigados não tenha sido capaz de realizar manobras de reanimação corretas por questões como peso e estatura insuficientes. ${ }^{17}$ 


\section{CONCLUSÃO}

Observou-se no presente estudo que os docentes e discentes apresentaram maior conhecimento referente ao ambiente onde se realiza a RCP, na identificação dos sinais clínicos de uma PCR, na relação compressão-ventilação, nos elos da cadeia de sobrevivência e na profundidade das compressões torácicas. No entanto, em questões mais específicas e aprofundadas, ocorreu percentual significativo de erros, com destaque nas situações especiais para a utilização do DEA, sinais para identificação de uma parada respiratória e os ritmos de uma PCR que são chocáveis.

Assim sendo, é possível que perguntas de maior grau de dificuldade, como as de número quatro e seis, possam ter influenciado de modo negativo no grau de assertividade dos entrevistados e resultado na impressão de que há um significativo deficit de conhecimento relativo à Suporte Básico de Vida entre os docentes e, principalmente, discentes do curso técnico em enfermagem. Ressalta-se que a elaboração das questões e teste em projeto piloto poderia ter permitido uma melhor compreensão desses assuntos e também do melhor modo para realizar sua abordagem.

Mesmo assim, diante de todo o exposto, é fato a necessidade de se investir na capacitação dos profissionais de enfermagem, principalmente com relação à utilização do DEA, uma vez que a questão referente a esse equipamento foi a que obteve maior percentual de erro. Nesse ínterim, é imprescindível exercitar o conhecimento em prol da melhora da assistência às vítimas que apresentam PCR e aumento das chances de sobrevida desses pacientes.

Salienta-se que embora existam disciplinas específicas para o ensino do $\mathrm{SBV}$, nas quais os docentes se preparam para ministrar os referidos conteúdos, fazse necessária a obtenção desse conhecimento por professores de enfermagem de todas as áreas, já que o enfermeiro docente, seja de curso técnico ou graduação, é responsável por formar profissionais generalistas. Por fim, apesar do trabalho responder ao objetivo do estudo, houve como limitação a participação de indivíduos de uma única instituição de ensino, o que dificulta a generalização dos resultados. Portanto, recomenda-se a execução de pesquisas semelhantes em outras instituições, tanto no cenário nacional quanto no mundial.

\section{REFERÊNCIAS}

1. Gonzalez MM, Timerman S, Gianotto-Oliveira R, Polastri TF, Canesin MF, Schimidt A, et al. I Diretriz de ressuscitação cardiopulmonar e cuidados cardiovasculares de emergência da Sociedade Brasileira de Cardiologia. Arq 
Bras Cardiol. [Internet]. 2013 [citado em 19 jun 2019]; 101(2):1-240. Disponível em: https://www.scielo.br/pdf/abc/v101n2s3/v1 01n2s3.pdf

2. Caveião C, Sales WB, Brey C, Scussiato LA, Carneiro GMB, Oliveira AC. Conhecimento de acadêmicos de enfermagem acerca das diretrizes de reanimação cardiopulmonar no suporte básico de vida para adultos. Rev Ciênc Saúde On-line [Internet]. 2017 [citado em 09 out 2020]; 2(3):1-7. Disponível em: https://revistaeletronicafunvic.org/index.ph $\mathrm{p} / \mathrm{c} 14 \mathrm{ffd} 10 /$ article/view/86.

3. Canova JCM, Cyrillo RMZ, Hayashida M, Pompeo DA, Ribeiro RCH, Dalri MCB. Parada cardiorrespiratória e ressuscitação cardiopulmonar: vivências da equipe de enfermagem sob o olhar da técnica do incidente crítico. Rev Enferm UFPE on line [Internet]. 2015 [citado em 19 jun 2019]; 2(9):7095-103. Disponível em:

https://periodicos.ufpe.br/revistas/revistaen fermagem/article/view/10439/11243

4. Silva KR, Araújo AST, Almeida WS, Pereira IVDS, Carvalho EAP, Abreu MNS. Parada cardiorrespiratória e o suporte básico de vida no ambiente préhospitalar: o saber acadêmico. Saúde (Santa Maria) [Internet]. 2017 [citado em 19 jun 2019]; 43(1):53-9. Disponível em: https://periodicos.ufsm.br/revistasaude/arti cle/view/22160/pdf

5. Costa CRB, Melo ES, Reis RK. Simulação no ensino de emergência para estudantes de enfermagem. Rev Cuid. [Internet]. 2020 [citado em 09 out 2020]; 11(2):e853. Disponível em: https://revistacuidarte.udes.edu.co/index.ph p/cuidarte/article/view/853/1535

6. Silva RS. Pós-graduação e a pesquisa em enfermagem na América Latina: avanços e desafios. Rev Cuid. [Internet]. 2015 [citado em 09 out 2020]; 6(2):1019-21. Disponível em: https://www.redalyc.org/pdf/3595/3595407 42001.pdf
7. Silva DV, Jesus APS, Lima AA, Santos MSA, Alves SL. Conhecimento de graduandos em enfermagem sobre suporte básico de vida. Rev Baiana Enferm. [Internet]. 2015 [citado em 09 out 2020]; 29(2):125-34. Disponível em: https://portalseer.ufba.br/index.php/enferm agem/article/view/12648/pdf_126.

8. American Heart Association.

Destaques das diretrizes de RCP e ACE de 2020 da American Heart Association.

Dallas, Texas: American Heart

Association; 2020.

9. Mundin TB. Ressuscitação

cardiopulmonar: analise do atendimento pré-hospitalar na cidade de Ribeirão Preto de 2011 a 2013 [dissertação]. Ribeirão Preto, SP: Universidade de São Paulo; 2015.

10. Monteiro, MJFSP, Pereira MCARS, Carvalho RMBC, Carril ÉSB, Carril MFB, Rodrigues VMCP. Capacitação de trabalhadores em suporte básico de vida. Rev Cuid. [Internet]. 2018 [citado em 30 dez 2020]; 9(2)2117-26. Disponível em: http://www.scielo.org.co/pdf/cuid/v9n2/23 46-3414-cuid-9-2-2117.pdf

11. Bernoche C, Timerman S, Polastri TF, Giannetti NS, Siqueira AWS, Piscopo A, et al. Atualização da diretriz de ressuscitação cardiopulmonar e cuidados de emergência da Sociedade Brasileira de Cardiologia - 2019. Arq Bras Cardiol. [Internet]. 2019 [citado em 09 out 2020]; 113(3):449-663. Disponível em: https://www.scielo.br/pdf/abc/v113n3/006 6-782X-abc-113-03-0449.pdf

12. Ferreira JVB, Ferreira SMB, Casseb GB. Perfil e conhecimento teórico de médicos e enfermeiros em parada cardiorrespiratória, município de Rio Branco, AC. Rev Bras Cardiol. [Internet]. 2012 [citado em $30 \mathrm{dez} 2020$ ]; 25(6):46470. Disponível em:

http://www.onlineijcs.org/english/sumario/ 25/pdf/v25n6a04.pdf

13. Alves CA, Barbosa CNS, Faria HTG. Parada cardiorrespiratória e enfermagem: o conhecimento acerca do suporte básico de 
vida. Cogitare Enferm. [Internet].

2013[citado em 30 dez 2020]; 2(18):296-

301. Disponível em:

https://revistas.ufpr.br/cogitare/article/view

/32579/20693

14. Farias VE, Felini K, Macedo JM,

Mattos MR. Sistematização da assistência

de enfermagem diante da parada

cardiorespiratória (PCR). Rev Thêma et

Scientia [Internet]. 2015 [citado em 09 out 2020]; 5(1e):72-82. Disponível em:

http://www.themaetscientia.fag.edu.br/inde

x.php/RTES/article/view/1225/1125

15. Câmera dos Deputados (Brasil).

Projeto de Lei n. 736 de 2015. Dispõe

sobre a manutenção de desfibrilador

cardíaco em locais especificados de todo o

território nacional e dá outras providências.

Brasília, DF: Câmara dos Deputados;

2015.

16. Nakahara S, Sakamoto T. Effective deployment of public-access automated external defibrillators to improve out-ofhospital cardiac arrest outcomes. J Gen Fam Med. [Internet]. 2017 [citado em 30 dez 2020]; 18(5):217-24. Disponível em: https://www.ncbi.nlm.nih.gov/pmc/articles /PMC5689421/pdf/JGF2-18-217.pdf 17. Barbosa HGD, Santana LR, Nicolini EM. Avaliação do impacto e efetividade do treinamento de crianças em suporte básico de vida. Rev Med. (São Paulo). [Internet]. 2020 [citado em $30 \mathrm{dez}$ 2020]; 99(1):56-61. Disponível em:

https://www.revistas.usp.br/revistadc/articl e/view/164675/159090

RECEBIDO: $27 / 11 / 2019$

APROVADO: 06/01/2021

PUBLICADO: 03/2021 